\title{
12-O-Tetradecanoyl-Phorbol-13-Acetate Release of Glycosyltransferases from Human Blood Cells
}

\author{
Chen-Kao Liu, Robert Schmied, and Samuel Waxman, Cancer Chemotherapy \\ Foundation Laboratory, Division of Medical Oncology, Department of Medicine \\ and Biochemistry, Mount Sinai School of Medicine, New York 1002.9
}

\begin{abstract}
A B S T R A C T The mononuclear cells separated from human blood by Ficoll-Hypaque centrifugation contained and released sialyltransferase, galactosyltransferase, and fucosyltransferase. Granulocytes contained and released lesser amounts of glycosyltransferases, whereas platelets released more fucosyltransferase than sialyltransferase or galactosyltransferase. When mononuclear cells were incubated with $12-O$ tetradecanoyl-phorbol-13-acetate (TPA), the release of these three glycosyltransferases increased two- to sixfold, and cell suspension glycosyltransferase activities decreased $10-50 \%$. Mononuclear cells were fractionated into lymphocytes and monocytes using baby hamster kidney cells microexudate-coated flasks. TPA stimulated the release of glycosyltransferases from lymphocytes but not from monocytes. The release of glycosyltransferases by TPA-treated mononuclear cells was not further stimulated by reincubation with TPA and was not affected by puromycin, cAMP, or cGMP. Concanavalin A, a mitogenic stimulator of lymphocytes, also stimulated the release of glycosyltransferases from mononuclear cells, but to a lesser extent. TPA did not stimulate the release of $5^{\prime}$-nucleotidase or decrease its activity on the cell pellet. Triton X-100 $(0.2 \%)$ stimulated the release of glycosyltransferases to the same extent as TPA, but also caused the release of $5^{\prime}$-nucleotidase. $\left[{ }^{3} \mathrm{H}\right] \mathrm{TPA}$ bound specifically and reversibly to mononuclear cells. The possible relationship between glycosyltransferase release and TPA effect on the plasma membrane is discussed.
\end{abstract}

\section{INTRODUCTION}

12-O-tetradecanoyl-phorbol-13-acetate $(\mathrm{TPA})^{1}$ is the most active tumor-promoting agent isolated from

Received for publication 2 October 1979 and in revised form 11 February 1980.

${ }^{1}$ Abbreviations used in this paper: DMSO, dimethyl sulfoxide; FT, fucosyltransferase; GT, galactosyltransferase; PBS, phosphate-buffered saline; ST, sialyltransferase; TPA, 12-O-tetradecanoyl-phorbol-13-acetate. croton oil (1). It acts as an inflammatory agent (2) and induces several responses representative of many critical biological reactions occurring in mammalian cells $(3,4)$. These include stimulation of macromolecular biosynthesis, induction of certain enzymes, and alteration of plasma membrane function.

Most proteins in the plasma membrane are glycosylated, and increasing evidence (5-7) implicates surface carbohydrate moieties as important determinants in embryonic differentiation, cell proliferation, neoplastic transformation, and immunological responsiveness. Glycosyltransferases, which are necessary for the biosynthesis of glycoprotein, are mainly localized in the endoplasmic reticulum and Golgi apparatus (8), but many are also found on the cell surface (9). Changes of glycosyltransferase have been demonstrated in transformed cells (10).

As an attempt to understand the relationship between glycosyltransferase and neoplastic transformation, we have studied the effect of TPA on human blood cell glycosyltransferases. This report demonstrates that TPA can stimulate the specific release of glycosyltransferases from human lymphocytes. Some of these results have been reported in abstract form (11).

\section{METHODS}

Materials. Lymphocyte separation medium was from Bionetics Laboratory Products, Litton Bionetics Inc., Kensington, Md.; TPA, other phorbol derivatives, concanavalin A, dibutyryl-cAMP, dibutyryl-cGMP, 2-glycerol-phosphate, puromycin, phenobarbital, and fetuin were obtained from Sigma Chemical Co., St. Louis, Mo.; CMP-[4,5,6,7,8,9,$\left.{ }^{14} \mathrm{C}\right]$ sialic acid, UDP- $\left[1-{ }^{3} \mathrm{H}(\mathrm{N})\right]$ galactose, $\left[20-{ }^{3} \mathrm{H}(\mathrm{N})\right] \mathrm{TPA}$ were from New England Nuclear, Boston, Mass.; and GDP-[1$\left.{ }^{14} \mathrm{C}\right]$ fucose was from ICN Nutritional Biochemicals, Cleveland, Ohio.

Mononuclear leukocytes and granulocytes were isolated from human blood of normal donors by the Ficoll-Hypaque and dextran sedimentation methods (12). The mononuclear leukocytes were further fractionated using baby hamster kidney microexudate-coated flasks according to Ackerman and Douglas (13). Washed mononuclear leukocytes $\left(2 \times 10^{7}\right.$ cells) from the Ficoll-Hypaque technique were suspended in 
$10 \mathrm{ml}$ complete medium containing Eagle's minimal essential medium supplemented with $20 \%$ fetal calf serum, glutamine, and nonessential amino acids, and pipetted into a $75-\mathrm{cm}^{2} \mathrm{cul}$ ture flask from which confluent baby hamster kidney cells had been removed with $10 \%$ EDTA in phosphate-buffered saline (PBS). After a $1-\mathrm{h}$ incubation at $37^{\circ} \mathrm{C}$, the medium with unattached cells, which consisted mainly of lymphocytes, was poured out. The lymphocyte fraction was washed twice with PBS. The attached cells in the flask, which consisted mainly of monocytes, were washed twice with complete medium and removed with $3 \mathrm{mM}$ EDTA. The obtained monocyte fraction was also washed twice with PBS. Platelets were obtained by centrifugation at $2,000 \mathrm{~g}$ for $30 \mathrm{~min}$ of washes from the mononuclear cell fraction. All the leukocyte fractions were found to contain at least $90 \%$ viable cells as judged by trypan blue uptake.

Fractionated human leukocytes $\left(8 \times 10^{6}\right.$ cells $)$ in $0.5 \mathrm{ml}$ PBS were incubated with or without $1 \mu$ l TPA, which was dissolved in DMSO (dimethyl sulfoxide) at a concentration of $0.1 \mathrm{mg} / \mathrm{ml}$. After a $1-\mathrm{h}$ incubation at $37^{\circ} \mathrm{C}$, the reaction mixture was either centrifuged at $500 \mathrm{~g}$ for $5 \mathrm{~min}$ and assayed for glycosyltransferase activities in both supernates and cell suspension or homogenized in a Dounce homogenizer and assayed for glycosyltransferase activities in the cell homogenates. After incubation with TPA, the leukocytes consisted of at least $80 \%$ viable cells as judged by trypan blue uptake. Experiments were performed with mononuclear cells unless otherwise stated.

Assays. The method of assaying sialyltransferase has been reported (14). A typical reaction mixture contained: $10 \mu \mathrm{l}$ of $0.25 \mathrm{M}$ sodium phosphate buffer, $\mathrm{pH} 7.0$, with $50 \mathrm{mM}$ $\mathrm{MgCl}_{2} ; 10 \mu \mathrm{l}$ of desialylated fetuin $(50 \mathrm{mg} / \mathrm{ml})(15) ; 50 \mu \mathrm{l}$ of sample; and $30 \mathrm{nmol}$ of CMP- $\left[{ }^{14} \mathrm{C}\right]$ sialic acid $(5,000 \mathrm{cpm} /$ nmol). Final volumes were made to $80 \mu \mathrm{l}$ with water. Incubations were carried out at $37^{\circ} \mathrm{C}$ for $2 \mathrm{~h}$. The reaction was stopped by adding $1 \mathrm{ml} 10 \%$ trichloroacetic acid, and the sialylated product was retained on Millipore filters (Millipore Corp., Bedford, Mass., HAWP02500). The filters were then washed three times with $1 \mathrm{ml} 10 \%$ trichloroacetic acid, put into vials with $10 \mathrm{ml}$ of Aquasol (New England Nuclear), and counted in a liquid scintillation counter (model LS-250, Beckman Instruments, Inc., Spinco Div., Palo Alto, Calif.).

The incubation mixture for the galactosyltransferase assay (16) consisted of: $10 \mu \mathrm{l}$ of $0.75 \mathrm{M} \mathrm{Na}$ cacodylate, $\mathrm{pH} 7.4$, with $0.375 \mathrm{M} \mathrm{NaCl}$, and $75 \mathrm{mM} \mathrm{MnCl}{ }_{2} ; 10 \mu \mathrm{l}$ of fetuin free of sialic acid and galactose $(50 \mathrm{mg} / \mathrm{ml})(17) ; 6.5 \mathrm{nmol}$ of UDP$\left[{ }^{3} \mathrm{H}\right]$ galactose $(13,600 \mathrm{cpm} / \mathrm{nmol})$; and $50 \mu \mathrm{l}$ of sample. The assay was terminated after a 2 -h incubation at $37^{\circ} \mathrm{C}$. Amount of product formation was determined as described above for sialyltransferase.

The incubation mixture for the fucosyltransferase assay (18) contained: $10 \mu \mathrm{l}$ of $0.375 \mathrm{M}$ Tris- $\mathrm{HCl}, \mathrm{pH} 7.0$, with 18.75 mM EDTA, and $0.75 \%$ Triton X-100;10 $\mu$ l of fetuin free of sialic acid and galactose $(50 \mathrm{mg} / \mathrm{ml}) ; 0.4$ nmole of GDP$\left[1-{ }^{14} \mathrm{C}\right]$ fucose $(97,000 \mathrm{cpm} / \mathrm{nmol})$; and $50 \mu$ l of sample. Enzyme activity was determined as described above for sialyltransferase.

For the binding assay, $10 \mathrm{ng}\left[{ }^{3} \mathrm{H}\right] \mathrm{TPA}(22,000 \mathrm{cpm} / \mathrm{ng})$ was added to the mononuclear cells $\left(10^{6}\right.$ cells $)$ and the mixture was incubated at $37^{\circ} \mathrm{C}$ for $10 \mathrm{~min}$. Cold TPA was added as indicated in Table VII. The cell pellets were collected by centrifugation, washed twice with PBS, solubilized in NCS tissue solubilizer (Nuclear-Chicago, Des Plaines, Ill.), and counted.

The incubation mixture for the $5^{\prime}$-nucleotidase assay contained (19): $0.1 \mathrm{ml}$ of $0.2 \mathrm{M}$ Tris- $\mathrm{HCl}, \mathrm{pH} 8.7$, with $80 \mathrm{mM}$ $\mathrm{MgCl}_{2}$ and $0.2 \mathrm{mM}$ 2-glycerophosphate; $250 \mathrm{nmol}$ of $\left[2-{ }^{3} \mathrm{H}\right]-$ AMP $(80,000 \mathrm{cpm})$; and $0.1 \mathrm{ml}$ of sample. Final volume was made to $0.4 \mathrm{ml}$ with water. The reaction was stopped by adding $0.1 \mathrm{ml}$ of $0.25 \mathrm{M} \mathrm{ZnSO}_{4}$ after a 1 -h incubation at $37^{\circ} \mathrm{C}$. $0.1 \mathrm{ml}$ of $0.25 \mathrm{M} \mathrm{Ba}(\mathrm{OH})_{2}$ was added to the reaction mixture, which was then centrifuged at $1,500 \mathrm{~g}$ for $15 \mathrm{~min}$ and $0.1 \mathrm{ml}$ of the supernate was counted.

\section{RESULTS}

The human mononuclear cell suspension contains and releases sialyltransferase (ST), galactosyltransferase (GT), and fucosyltransferase (FT) activities. When the cells are incubated with TPA for $1 \mathrm{~h}$, the amount of glycosyltransferase release is increased 2- to 10 -fold, whereas the cell suspension glycosyltransferase activities are decreased $10-50 \%$. (Table I). Cells preincubated with TPA cannot be further stimulated by TPA to relase more glycosyltransferases, because cells preincubated with TPA and assayed with TPA do not show higher activities than cells only preincubated with TPA. Similar results were obtained from four blood donors. The ranges of glycosyltransferase activities $(\mathrm{cpm} / 2 \mathrm{~h}$ per $50 \mu \mathrm{l})$ in control supernate $(1-\mathrm{h}$ incubation at $37^{\circ} \mathrm{C}$, without TPA) are: ST, $310-1,190$; GT, 110-830; FT 580-890. The ranges of glycosyltransferase activities in TPA-treated supernate are: ST, 850-4,120; GT, 1,050-3,012; FT, 1,290-1,960. Similar results are obtained when 0.05 to $1 \mu \mathrm{g}$ of TPA (in $1 \mu \mathrm{l}$ of DMSO) are used. Much higher or lower TPA concen-

TABLE I

Stimulation of Glycosyltransferase Release from Human Mononuclear Cells by TPA*

\begin{tabular}{lrrr}
\hline & \multicolumn{3}{c}{ Glycosyltransferase activity } \\
\cline { 2 - 5 } & ST & GT & FT \\
\hline & \multicolumn{3}{c}{$c p m / 10^{6}$ cells/2 $h$} \\
Supernate & 480 & 560 & 680 \\
Control & 490 & 510 & 620 \\
Assayed with TPA & 3,540 & 2,190 & 1,430 \\
From cells preincubated with TPA & & & \\
Cell suspension & 290 & 1,090 & 1,530 \\
Control & 2,530 & 1,890 & 1,830 \\
Assayed with TPA & 200 & 610 & 1,300 \\
From cells preincubated with TPA & & & \\
$\quad$ From cells preincubated with TPA & 160 & 410 & 1,100 \\
$\quad$ and assayed with TPA & & & \\
\hline
\end{tabular}

* $0.5 \mathrm{ml}$ human mononuclear cells $\left(10^{7}\right.$ cells $)$ were preincubated with or without $0.1 \mu \mathrm{G}$ TPA (in $1 \mu \mathrm{l}$ DMSO) at $37^{\circ} \mathrm{C}$ for $1 \mathrm{~h}$. After centrifugation at $500 \mathrm{~g}$ for $5 \mathrm{~min}, 50 \mu \mathrm{l}$ of supernate was used for each assay as described in Methods. To assay the cell suspension glycosyltransferase activities, the cell pellet was suspended in $0.5 \mathrm{ml}$ PBS and $50 \mu \mathrm{l}$ of the cell suspension was used for each assay. The assay mixture for cell suspension glycosyltransferase activity contained additional $\mathrm{NaCl}$ to a final concentration of $0.15 \mathrm{M}$. Preparation of mononuclear cells is described in Methods. 
trations result in nonreproducible data. The addition of TPA at $0.2 \mu \mathrm{g} / \mathrm{ml}$ does not affect the glycosyltransferase assay of supernate and cell suspension pretreated with TPA. The release of glycosyltransferase by mononuclear cells is linear vs. time up to $1 \mathrm{~h}$ and is temperature dependent, whereas the optimum amount of glycosyltransferase release in the presence of TPA is reached within $15 \mathrm{~min}$ and is not dependent on temperature. DMSO alone at $0.2 \%$ does not affect the glycosyltransferase release. Although the mononuclear cell fraction contains platelets $\left(<10^{6}\right.$ platelets per assay tube), it is unlikely that the mononuclear cell response to the TPA can be attributed to platelet contamination, since the platelets alone do not show a significant TPA effect (see Table II, as compared with Table I).

The glycosyltransferase assays of supernate and cell suspension are linear with time up to $2 \mathrm{~h}$, and are proportional to the amount of supernate and the number of cells added up to $1.5 \times 10^{6}$ cells/tube. Intact mononuclear cells require exogeneous acceptor for the glycosyltransferase assay, and addition of $5 \mathrm{mM}$ galactose does not affect the cell suspension GT assay (Table III). Boiling the cells for 5 min completely destroys their GT activity. DMSO, at the concentration used for TPA stimulation, does not affect GT activity. Treatment of the mononuclear cell suspension with $1 \%$ Triton X-100 also greatly increases the assayable GT activity. If this amount is counted as the total GT of

TABLE II

Effect of TPA on Glycosyltransferase Release from Human Granulocytes and Platelets

\begin{tabular}{lrrr}
\hline & \multicolumn{3}{c}{$\begin{array}{c}\text { Glycosyltransferase } \\
\text { activity }\end{array}$} \\
\cline { 2 - 4 } & ST & GT & FT \\
\hline Granulocytes & & $c m m / 50 \mu l^{*} / 2 h$ & \\
$\quad$ Control cells & & & \\
$\quad$ Cell suspension & NA $\ddagger$ & 790 & NA \\
$\quad$ Supernate & NA & 380 & NA \\
Cells preincubated with TPA & & & \\
$\quad$ Cell suspension & NA & 540 & NA \\
$\quad$ Supernate & NA & 1,050 & NA \\
Platelets & & & \\
Control cells & & & \\
$\quad$ Cell suspension & & & \\
$\quad$ Supernate & 2,320 & 2,110 & 1,760 \\
Cells preincubated with TPA & 110 & 50 & 1,370 \\
$\quad$ Cell suspension & & & \\
$\quad$ Supernate & 2,400 & 2,080 & 1,520 \\
& 420 & 320 & 1,910 \\
\hline
\end{tabular}

* Contain $10^{6}$ granulocytes or $10^{7}$ platelets in the preincubation mixture and in the cell suspension assay. Granulocytes and platelets were prepared as described in Methods.

\$ NA, negligible amount.
TABLE III

Assay of GT Activity in

Mononuclear Cell Suspension

\begin{tabular}{lc}
\hline \multicolumn{1}{c}{ Cell suspension } & GT activities* \\
\hline & $c p m / 10^{6}$ cells/2 $h$ \\
Control & 1,250 \\
Minus SGF-fetuin $\$$ & 75 \\
Minus cell & 76 \\
Boiling cell suspension $\$$ & 70 \\
With TPA (0.1 $\mu$ g in 0.1 $\mu$ l DMSO) & 3,190 \\
With TPA, minus SGF-fetuin & 90 \\
With 0.1 $\mu$ l DMSO & 1,260 \\
With 5 mM galactose & 1,220 \\
With 0.1\% Triton X-100 & 3,280 \\
With $1 \%$ Triton X-100 & 3,840 \\
\hline
\end{tabular}

* $50 \mu \mathrm{l}$ of mononuclear cells $\left(10^{6}\right.$ cells) were assayed for its GT activity in various conditions. Cells, except those treated with Triton X-100, were at least $80 \%$ viable after the 2 -h incubation as judged by trypan blue uptake.

\$ SGF-fetuin, fetuin free of sialic acid and galactose.

$\S$ In boiling water for $2 \mathrm{~min}$.

the mononuclear cell, than $50 \%$ of this cellular GT is released into the supernate by TPA $[(3,190-1,250)$ $\div 3,840$, see Table II].

The mononuclear cell fraction obtained by the Ficoll-Hypaque method contains 90\% lymphocytes and $10 \%$ monocytes. This mononuclear cell fraction can be further fractionated by incubation in baby hamster kidney cell microexudate-coated flasks (13). The monocyte fraction thus obtained, consisting of $80 \%$ monocytes, contains and releases little glycosyltransferase activity and is not stimulated by TPA (Table IV). The lymphocyte fraction, devoid of monocytes, releases glycosyltransferases; this release is stimulated by TPA but to a lesser extent than the release from unfractionated mononuclear cells. Therefore, it is likely that lymphocytes, rather than monocytes, are responsible for the TPA stimulation observed in the mononuclear cell fraction. The decrease in glycosyltransferase release and TPA stimulation in the isolated lymphocyte fraction may be caused by continuous release of glycosyltransferases during the process of fractionation. A mixture of monocytes and lymphocytes still releases lesser amounts of glycosyltransferases than unfractionated mononuclear cells.

The TPA effect on glycosyltransferase release does not require the intact cell, since TPA also stimulates glycosyltransferase activities in the cell homogenate. This is shown in Table $\mathrm{V}$. The extent of stimulation by TPA of the cell homogenate is similar to that of the intact cell.

The granulocyte contains and releases GT, but little ST or FT (Table II). When granulocytes are prein- 
TABLE IV

Effect of TPA on Glycosyltransferase Release from Purified Lymphocytes and Monocytes*

\begin{tabular}{lcr}
\hline & \multicolumn{2}{c}{$\begin{array}{c}\text { Glycosyltransferase } \\
\text { activity }\end{array}$} \\
\cline { 2 - 3 } \multicolumn{1}{c}{ Supernate from } & ST & GT \\
\hline & $c p m / 50 \mu l / 2 h$ \\
Control & & \\
Unfractionated mononuclear cells & 468 & 551 \\
Lymphocytes & 270 & 214 \\
Monocytes & 118 & 134 \\
Combined lymphocytes and monocytes & 352 & 324 \\
Cells preincubated with TPA & & \\
Unfractionated mononuclear cells & 1,977 & 1,607 \\
Lymphocytes & 1,057 & 444 \\
Monocytes & 136 & 155 \\
Combined lymphocytes and monocytes & 1,172 & 573 \\
\hline
\end{tabular}

* Lymphocytes and monocytes were prepared as described in Methods.

cubated with TPA, GT release is increased three- to sixfold and cell suspension GT activity is slightly decreased. The platelet contains all three glycosyltransferases and releases little of them, except for FT. TPA does not stimulate the glycosyltransferase release from platelets.

TPA and phorbol didecanoate have tumor-promoting and inflammatory activities in mouse skin, whereas phorbol and 4- $\alpha$-phorbol didecanoate do not (20). Mezerein is an antileukemic agent which resembles TPA in its ability to inhibit cell differentiation and to enhance plasminogen activator production (21). Table VI shows that only those compounds that possess inflammatory and tumor-promoting activity can stimulate ST release and decrease cell suspension ST activity of mononuclear cells.

TABLE $\mathrm{V}$

TPA Effect on Glycosyltransferase Activities of Mononuclear Cell Homogenate*

\begin{tabular}{lrrr}
\hline & \multicolumn{3}{c}{ Glycosyltransferase activity } \\
\cline { 2 - 5 } & ST & GT & FT \\
\hline & \multicolumn{4}{c}{$c p m / 10^{6}$ cells/2 $h$} \\
Intact cell suspension & 870 & 1,260 & 900 \\
Cell homogenate & & & \\
$\quad$ Control & 910 & 1,470 & 930 \\
Assayed with TPA & 3,110 & 2,960 & 1,260 \\
From cells preincubated with TPA & 2,920 & 2,860 & 1,340
\end{tabular}

* Mononuclear cells were preincubated with or without TPA and then homogenized in a Dounce homogenizer. The homogenates were assayed for glycosyltransferase activities in the presence or absence of TPA.
TABLE VI

Effect of Phorbol Derivatives on Sialyltransferase Release from Human Mononuclear Cells

\begin{tabular}{|c|c|c|c|c|}
\hline & \multirow{2}{*}{\multicolumn{2}{|c|}{ Sialyltransferase activity }} & \multicolumn{2}{|c|}{ Activity in mouse skin* } \\
\hline & & & \multirow{2}{*}{$\begin{array}{c}\text { Tumor } \\
\text { promotion }\end{array}$} & \multirow{2}{*}{$\begin{array}{l}\text { Inflam- } \\
\text { mation }\end{array}$} \\
\hline & Supernate & Pellet & & \\
\hline \multicolumn{5}{|c|}{$\mathrm{cpm} / 10^{6} \mathrm{cells} / 2 \mathrm{~h}$} \\
\hline None & 430 & 520 & & \\
\hline Phorbol & 490 & 520 & - & - \\
\hline TPA & 930 & 290 & + & + \\
\hline Phorbol & & & & \\
\hline $\begin{array}{l}\text { didecanoate } \\
\text { 4- } \alpha \text {-phorbol }\end{array}$ & 820 & 220 & + & + \\
\hline didecanoate & 560 & 600 & - & - \\
\hline Mezerein & 760 & 250 & & \\
\hline
\end{tabular}

* See references 20 and 21.

Stimulation of ST release by TPA is not greatly affected by the presence of cyclic nucleotides or puromycin, an inhibitor of protein synthesis, and does not require the presence of serum, as shown on Table VII. The cyclic nucleotides by themselves do not affect ST or GT release. Concanavalin A, a mitogenic stimulator of lymphocytes, stimulates glycosyltransferase release, but to a lesser extent than TPA. Phenobarbital, a tumor-promoting agent of rat liver, does not have the stimulatory effect.

TPA binding to the plasma membrane of murine lymphocytes has been demonstrated (22) by means of cell fractionation studies. Fig. 1 shows that TPA binds

TABLE VII

Effectors of TPA Stimulation of Glycosyltransferase Release

\begin{tabular}{|c|c|c|}
\hline \multirow{2}{*}{$\begin{array}{l}\text { Supernate from mononuclear } \\
\text { cells treated with* }\end{array}$} & \multicolumn{2}{|c|}{ Glycosyltransferase activity } \\
\hline & ST & GT \\
\hline & \multicolumn{2}{|c|}{$\mathrm{cpm} / 10^{6} \mathrm{cells} / 2 \mathrm{~h}$} \\
\hline None & 480 & 560 \\
\hline TPA & 1,960 & 3,590 \\
\hline TPA with cAMP, $0.5 \mathrm{mM}$ & 1,830 & 3,120 \\
\hline CAMP & 400 & 590 \\
\hline TPA with cGMP, $0.5 \mathrm{mM}$ & 1,790 & 2,420 \\
\hline cGMP & 320 & 580 \\
\hline TPA with puromycin, $0.5 \mu \mathrm{g}$ & 2,290 & 2,900 \\
\hline Concanavalin A, $50 \mu \mathrm{g}$ & 650 & 940 \\
\hline Phenobarbital, $10 \mu \mathrm{g}$ & 450 & 540 \\
\hline No serum & 550 & 470 \\
\hline No serum with TPA & 2,270 & 3,010 \\
\hline
\end{tabular}

* Cell suspension in complete medium $\left(0.5 \mathrm{ml}\right.$ with $10^{7}$ cells $)$ was incubated with indicated reagents at $37^{\circ} \mathrm{C}$ for $1 \mathrm{~h}$. The reaction mixture was then centrifuged at $1,000 \mathrm{~g}$ for $10 \mathrm{~min}$, and $50 \mu \mathrm{l}$ of the supernate was used for each assay. 


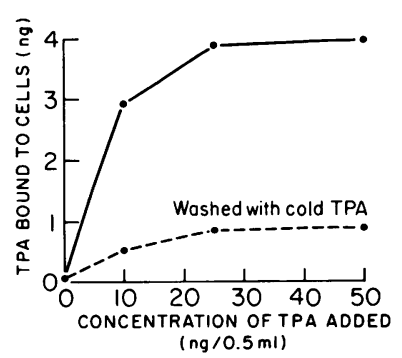

FIGURE 1 The effect of TPA concentration on its binding to mononuclear cells. $\left[{ }^{3} \mathrm{H}\right] \mathrm{TPA}$ binding assay has been described in Methods. Nonradioactive TPA was added to the $\left[{ }^{3} \mathrm{H}\right]$ TPA (10 ng, 22,000 cpm) to obtain the designated concentrations. After incubation at $37^{\circ} \mathrm{C}$ for $10 \mathrm{~min}$, the cells were washed by PBS with (- $)$ or without $(---)$ TPA $(0.1 \mu \mathrm{g} / \mathrm{ml})$.

to human mononuclear cells at a saturable level of $4 \mathrm{ng}$ per $10^{6}$ cells. TPA-treated cells bind less $\left[{ }^{3} \mathrm{H}\right] \mathrm{TPA}$, and the bound $\left[{ }^{3} \mathrm{H}\right] \mathrm{TPA}$ can be partially washed out by nonradioactive TPA. This demonstrates that TPA can specifically and reversibly bind to mononuclear cells.

The TPA increase in medium glycosyltransferase of mononuclear cells may be through its detergent effect. Therefore, we have compared the effects of TPA and Triton X-100, a generally used detergent, on the release of glycosyltransferases and the membranebound enzyme 5'-nucleotidase from mononuclear cells. Most 5'-nucleotidase is found in the cell pellet of mononuclear cells, and little is released into the medium (Table VIII). TPA does not stimulate its release or decrease its cell pellet activity, while Triton $\mathrm{X}-100$, at $0.2 \%$, releases most 5 '-nucleotidase from the mononuclear cells into the medium. Release of ST and GT is also stimulated by Triton X-100, and to the same extent as by TPA.

TABLE VIII

Effect of TPA and Triton X-100 on ST and 5'-Nucleotidase Release from Mononuclear Cells

\begin{tabular}{|c|c|c|}
\hline & 5 '-Nucleotidase & ST \\
\hline & nmoll110 cells/h & $\mathrm{cpm} / 10^{6}$ cells $/ 2 \mathrm{~h}$ \\
\hline \multicolumn{3}{|l|}{ Control cells } \\
\hline Cell pellet & 10.4 & 410 \\
\hline Supernate & 1.5 & 620 \\
\hline Homogenate & 12.1 & 970 \\
\hline \multicolumn{3}{|c|}{ Cells treated with TPA } \\
\hline Cell pellet & 8.2 & 320 \\
\hline Supernate & 1.3 & 2,590 \\
\hline Homogenate & 11.0 & 2,610 \\
\hline \multirow{2}{*}{\multicolumn{3}{|c|}{ Cells treated with $0.2 \%$}} \\
\hline & & \\
\hline Cell pellet & 4.9 & 310 \\
\hline Supernate & 9.6 & 2,480 \\
\hline
\end{tabular}

\section{DISCUSSION}

We have shown that human mononuclear cells can be stimulated by TPA to release two- to fivefold more glycosyltransferase activities into the culture medium. This increased release of glycosyltransferase into the culture medium cannot be caused by increased biosynthesis of these enzymes because TPA stimulation is not affected by an inhibitor of protein synthesis and also because TPA-treated cells cannot be further stimulated to release more glycosyltransferases when TPA is added to the assay mixture. The release of glycosyltransferase by TPA is not the result of increased cell breakage either, because disruption of cells by homogenization does not significantly increase the soluble glycosyltransferase activities. TPA has been demonstrated to interact with cellular membranes and to alter membrane-associated enzyme functions (22). It is likely that the increased release of cellular glycosyltransferases combined with the decrease in cell suspension glycosyltransferase activities of TPA-stimulated mononuclear cells is caused by the perturbation by TPA of the plasma membrane. The origin of the glycosyltransferases released into the culture medium is not known. Several of our results indicate that the glycosyltransferases assayed in cell suspension are located on the external surface of the plasma membrane. (a) Enzymatic activity required the presence of fetuin, which presumably will not enter the cell. (b) Addition of free galactose to the assay system for galactosyltransferase did not significantly reduce galactosyltransferase activity. Inhibition would be expected if the assay required hydrolysis of UDP-galactose to galactose. Therefore, the activity found was not dependent upon hydrolysis of UDP-galactose followed by internalization of galactose. (c) Although the mononuclear cells did release glycosyltransferases into the culture medium in a linear fashion, linear response of glycosyltransferase activity in cell suspension with respect to time indicated that the available enzyme amount in cell suspension was constant through the assay period and therefore this activity was little affected by released glycosyltransferase. Cells surface galactosyltransferase activity was also suggested in a recent report (23) which showed that the galactosyltransferase activity in cultured cells of human transitional cell carcinoma was mainly located in plasma membrane ghosts, and that there was little in other cell parts, including cell suspension, cell sap, endoplasmic reticulum, and Golgi apparatus. Therefore, it is possible that TPA-released glycosyltransferases come from plasma membrane. There are, however, two unexpected findings which are not explained. First, the amount of TPA-induced cell suspension glycosyltransferase decrease is considerably less than the increase in medium glycosyltransferases. Second, TPA 
stimulates homogenate similarly and to the same extent as intact cells. One possible reason is that some glycosyltransferase activity of intact cells is hidden inside the plasma membrane or within certain vesicles, and therefore is not available for glycosyltransferase assay even with homogenization, but can be released by TPA stimulation. It has been demonstrated (24) that TPA induces lysozyme release from human granulocytes, and perhaps TPA also induces glycosyltransferase release from some secretory vesicles. Apparently, our results do not exclude the possibility that glycosyltransferases released by TPA come from other internal organelles such as the Golgi apparatus.

The physiological relevance of the glycosyltransferase release to the tumor promoting or inflammatory effects of phorbol esters is not known. In several cell systems (25) phorbol esters induce changes in cell morphology and surface glycoproteins that mimic several of the characteristics of the phenotype of fully established tumor cells. A recent study (26) showed that treatment of human epithelial carcinoma cells with TPA for $24 \mathrm{~h}$ induced a marked morphological change and caused elevation of GT activity in cell homogenate, whereas treatment with butyric acid induced a morphological change different from TPA treatment and caused a significant depression in GT activity. Increase in cellular ceramide ST activity with accompanying changes of cell morphology induced by butyric acid have also been reported in human epithelial carcinoma (27) and rat ascites hepatoma cell cultures (28). These results suggest that the changes in cell morphology may be correlated with the cellular levels of various glycosyltransferases; and thus, the alteration in plasma membrane by TPA may be through its disturbing effect on the cell glycosyltransferase contents.

\section{ACKNOWLEDGMENTS}

This research was supported by a grant from the National Institutes of Health AM 16690-05, Chemotherapy Foundation, and the Gar Reichman Foundation.

\section{REFERENCES}

1. Hecker, E. 1968. Cocarcinogenic principles from the seed oil of croton tiglium and from other Euphorbiaceae. Cancer Res. 28: 2338-2349.

2. Berenblum, I. 1954. A speculative review: the probable nature of promoting action and its significance in the understanding of the mechanism of carcinogenesis. Cancer Res. 14: 471-477.

3. Diamond, L., T. G. O'Brien, and G. Rovera. 1978. Tumor promoters: effects on proliferation and differentiation of cells in culture. Life Sci. 23: 1979-1988.

4. Zabos, P., D. Kyner, N. Mendelsohn, C. Schrieber, S. Waxman, J. Christman, and G. Acs. 1978. Catabolism of 2-deoxyglucose by phagocyte leukocytes in the presence of 12-0-tetradecanoyl phorbol-13-acetate. Proc. Natl. Acad. Sci. U. S. A. 75: 5422-5426.
5. Fukuda, M., M. N. Fukuda, and S. I. Hakomori. 1979. Developmental change and genetic defect in the carbohydrate structure of band 3 glycoprotein of human erythrocyte membrane. J. Biol. Chem. 254: 3700-3703.

6. Ray, J., T. Shinnick, and R. Lerner. 1979. A mutation altering the function of a carbohydrate binding protein blocks cell-cell cohesion in developing Dictyostelium discoideum. Nature (Lond.). 279: 215-221.

7. Hymes, A. J., G. L. Mullinax, and F. Mullinax. 1979. Immunoglobulin carbohydrate requirement for formation of an IgG-IgG complex. J. Biol. Chem. 254: 3148-3151.

8. Schachter, H. 1974. The subcellular sites of glycosylation. Biochem. Soc. Symp. 40: 51-71.

9. Shur, B. D., and S. Roth. 1975. Cell surface glycosyltransferases. Biochim. Biophys. Acta. 415: 473-512.

10. Podolsky, D. K., M. M. Weiser, J. C. Westwood, and M. Gammon. 1977. Cancer-associated serum galactosyltransferase activity: demonstration in an animal system.J. Biol. Chem. 252: 1807-1817.

11. Liu, C. K., R. Schmied, C. Schrieber, and S. Waxman. 1979. Phorbol-12-myristrate-13-acetate (PMA) release of glycosyltransferases in human phagocytic leukocytes. Int. Congr. Biochem. Abstr. 11: 491.

12. Bøyum, A. 1974. Separation of blood leukocytes, granulocytes and lymphocytes. Tissue Antigens. 4: 269-274.

13. Ackerman, S. K., and S. D. Douglas. 1978. Purification of human monocytes on microexudate-coated surface. $J$. Immunol. 120: 1372-1374.

14. Liu, C. K., R. Schmied, and S. Waxman. 1979. The specific release of sialyltransferase by human hepatoma cell lines. Clin. Chim. Acta. 98: 225-233.

15. Bosmann, H. B. 1972. Platelet adhesiveness and aggregation. II. Surface sialic acid glycoprotein: $N$-acetylneuraminic transferase and neuraminidase of human blood platelets. Biochim. Biophys. Acta. 279: 456-474.

16. Lamont, J. T., J. L. Perrotto, M. W. Weiser, and K. J. Isselbacher. 1974. Cell surface galactosyltransferase and lectin agglutination of thymus and spleen lymphocytes. Proc. Natl. Acad. Sci. U. S. A. 71: 3726-3730.

17. Podolsky, D. K., and M. M. Weiser. 1975. Role of cell membrane galactosyltransferase in concanavalin A agglutination of erythrocytes. Biochem. J. 146: 213-221.

18. Chou, T. H., C. Murphy, and D. Kessel. 1977. Selective inhibition of a plasma fucosyltransferase by $N$-ethylmaleimide. Biochem. Biophys. Res. Commun. 74: 10011006.

19. Ip, C., and T. Dao. 1978. Alterations in serum glycosyltransferases and 5 '-nucleotidase in breast cancer patients. Cancer. Res. 38: 723-728.

20. Süss, R., G. Kreibich, and V. Kinzel. 1972. Phorbol esters as a tool in cell research? Eur. J. Cancer 8: 299-304.

21. Yamasaki, H., E. Fibach, U. Nudel, I. B. Weinstein, R. A. Rifkind, and P. A. Marks. 1977. Tumor promoters inhibit spontaneous and induced differentiation of murine erythroleukemia cells in culture. Proc. Natl. Acad. Sci. U. S. A. 74: 3451-3455.

22. Wenner, C. E., J. Moroney, and C. W. Porter. 1978. Early membrane effects of phorbol esters in 3T3 cells. In Carcinogenesis. Mechanisms of Tumor Promotion and Cocarcinogenesis. T. J. Slaga, A. Sivak, and R. K. Boutwell, editors. Raven Press, New York. 2: 363-378.

23. Plotkin, G. M., R. J. Wides, S. L. Gilbert, G. Wolf, I. K. Hagen, and G. R. Prout. 1979. Galactosyl transferase activity in human transitional cell carcinoma lines and in benign and neoplastic human bladder epithelium. Cancer Res. 39: 3856. (Abstr.)

24. Goldstein, I. M., S. T. Hoffstein, and G. Weissmann. 1975. 
Mechanisms of lysosomal enzyme release from human polymorphonuclear leukocytes. Effects of phorbol myristate acetate. J. Cell Biol. 66: 647-652.

25. Weinstein, I. B., M. Wigler, P. B. Fisher, E. Sisskin, and C. Pietropaolo. 1978. Cell culture studies on the biological effects of tumor promotors. In Carcinogenesis: Mechanisms of Tumor Promotion and Cocarcinogenesis. T. J. Slaga, A. Sivak, and R. K. Boutwell, editors. Raven Press, New York. 2: 313-333.

26. Marvel, C. C., J. R. Moskal, M. W. Lockney, and C. C. Sweeley. 1979. Changes in a glycoprotein galactosyltransferase activity from cultured human epithelial car- cinoma cells upon morphological differentiation with butyric acid and 12-0-tetradecanoylphorbol-13-acetate. XIth Int. Congr. Biochem. Abstr. 11: 492.

27. Macher, B. A., M. Lockney, J. R. Moskal, Y. K. Fung, and C. C. Sweeley. 1978. Studies on the mechanism of butyrate-induced morphological changes in KB cells. Exp. Cell Res. 117: 95-102.

28. Taki, T, Y. Hirabayashi, R. Kondo, and M. Matsumoto. 1979. Effect of butyrate on glycolipid metabolism of rat ascites hepatomas with different ganglioside metabolism. Int. Congr. Biochem. Abstr. 11: 493. 